\title{
TheraBite application in patients with trismus secondary to RIF (Radiation induced fibrosis) in oral and head neck cancer treated with laser fibrotomy - Our experience in 40 patients
}

\author{
R S Arora ${ }^{1}$, D G Adwani², Apurva Satish Deshpande ${ }^{3 *}$
}

${ }^{1}$ Onco Surgeon, Amravati Cancer Foundation and Sujaan Cancer Hospital And Research Centre, Amaravati, Maharashtra, INDIA. 2Professor \& HOD, 3PG Student, Department of Oralmaxillo-Facial Surgery, V Y W S Dental College and Hospital, Amaravati, Maharashtra, INDIA.

Email: satdeshpande@rediffmail.com

\begin{abstract}
Background: Head and neck cancer is a heterogeneous group of tumors situated in the larynx, nasal cavity, oral cavity, para-nasal sinuses or salivary glands. Incidence of head and neck cancer is about 650000 new cases per year and it is $6^{\text {th }}$ most common type of cancer worldwide in men and $8^{\text {th }}$ in women. The management and treatment of head and neck cancer is very challenging. Radiotherapy is used extensively in the treatment of head and neck cancer in conjunction with surgery or chemotherapy. Therapeutically most commonly used type of radiation causes damage to cells and tissues via direct DNA damage or production of reactive oxygen species that leads to localized inflammation. Radiation particularly results up to $45 \%$ Trismus in a patients who receives curative dose of therapy after 1-9 months. We treated 40 patients of radiation induced fibrosis. Dividing them then Group A and Group B with 20 cases each. After doing laser fibrotomy in all 40 patients Group A is treated with Tab Pentoxifylline, Tab Tocopherol and physiotherapy with Therabite. Group B treated by physiotherapy alone. we concluded that patients treated with Tab Pentoxifylline, Tab Tocopherol and Physiotherapy shows better result than physiotherapy alone.

Key Words : intra oral cancer, Radiotherapy induced fibrosis, trismus, TheraBite therapy.
\end{abstract}

*Address for Correspondence:

Dr Apurva Satish Deshpande, PG Student, Department of Oralmaxillo-Facial Surgery, V Y W S Dental College and Hospital, Amaravati, Maharashtra, INDIA.

Email: satdeshpande@,rediffmail.com

Received Date: 12/12/2019 Revised Date: 23/01/2020 Accepted Date: 30/03/2020

DOI: https://doi.org/10.26611/10191511

This work is licensed under a Creative Commons Attribution-NonCommercial 4.0 International License. $(\boldsymbol{( c )})$ EY-NC

\begin{tabular}{|l|l|}
\hline \multicolumn{2}{|c|}{ Access this article online } \\
\hline Quick Response Code: & Website: \\
\hline & www.medpulse.in \\
& \\
\hline
\end{tabular}

\section{INTRODUCTION}

Restricted mouth opening or trismus is defined as mouth opening less than $35 \mathrm{~mm}$ commonly associated with intra oral malignancies, head and neck cancer, after radiotherapy treatment, and submucus fibrosis. The prevalence of trismus ranges from $5-38 \%$. The consequences of trismus can result in problems with speech, oral hygiene, dental treatment, mandibular functioning, quality of life and follow up. Impaired health related quality life subsequently damages patient's physical and psychological health which in turn leads to poor mental condition and depression. Various devices have been applied in the treatment of fibrosis secondary to oral cavity cancer and radiotherapy induced fibrosis. These include mouth opening devices as tongue depressors, spatulas, rubber hose pipe for better mouth opening. Conventional exercise therapy increases mouth opening by some millimeters. Jaw stretching devices demonstrated efficacy in improving mouth opening in trismus. In this 
regard Dynasplint was tried. TheraBite is a patient controlled mechanical device with 2 mouth pieces that are inserted between teeth of upper and lower jaw. By squeezing handle, the mouth pieces open assisting mouth opening. The present study was undertaken to evaluate efficacy of TheraBite in patients of Radiation induced fibrosis posted for laser induced fibrotomy with restricted mouth opening.

\section{MATERIAL AND METHODS}

Therabite In all these patients laser induced fibrotomy was instituted under the effect of local infilteration of Lignocaine hydrochloride $2 \%$ with adrenaline $2-3 \mathrm{ml}$ surrounding to fibrotic area. After maximum release with laser therapy at multiple sites. TheraBite application was done. The patients were asked to hold 2 spatulasor beaks of Therabite, then stretching was done at the handles of the instument, it was maximally done so that patient's were able to tolerate the pain of stretching. These patients were asked to purchase the instrument and asked to perform the procedure at their home. All the patients were trained to use instrument and related instructions were given about using the instrument. These patients were followed at the intervals of 1 month, 2 months and 3 months. In Group A, we gave tab pentoxifylline, tab Tocopherol and physiotherapy and in group b we tried physiotherapy with Therabite after doing laser fibrotomy in radiation induced fibrosis patients.

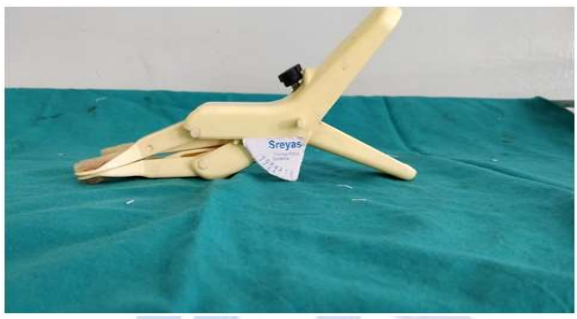

Table 1: Distribution of patients in two groups according to age in years

\begin{tabular}{cccc}
\hline Age Group & Group A & Group B & $\chi 2$-value \\
\hline $21-30$ yrs & $2(10 \%)$ & $0(0 \%)$ & \\
$31-40$ yrs & $5(25 \%)$ & $4(20 \%)$ & \\
$41-50$ yrs & $5(25 \%)$ & $9(45 \%)$ & 3.89 \\
$51-60$ yrs & $5(25 \%)$ & $3(15 \%)$ & $\mathrm{p}=0.42$, NS \\
$61-70$ yrs & $3(15 \%)$ & $4(20 \%)$ & \\
Total & $20(100 \%)$ & $20(100 \%)$ & \\
Mean \pm SD & $47.25 \pm 11.94$ & $48.60 \pm 11.07$ & \\
\hline
\end{tabular}

$10 \%$ of the patients in group A were in the age group of $21-30$ years, $25 \%$ in group A and $20 \%$ in group B were in the age group of 31-40 years, $25 \%$ in group A and $45 \%$ in group B were in the age group of $41-50$ years, $25 \%$ in group A and $15 \%$ in group B were in the age group of 51-60 years and 15\% of the patients in group A and $20 \%$ in group B were in the age group of 61-70 years and the distribution of age in two groups were statistically not $\operatorname{significant}(\chi 2-\mathrm{value}=3.89, \mathrm{p}=0.42)$.

Table 2: Distribution of patients in two groups according to their gender

\begin{tabular}{cccc}
\hline Gender & Group A & Group B & $\chi 2$-value \\
\cline { 1 - 3 } Male & $17(85 \%)$ & $15(75 \%)$ & \\
Female & $3(15 \%)$ & $5(25 \%)$ & 0.62 \\
\cline { 1 - 3 } Total & $\mathbf{2 0 ( 1 0 0 \% )}$ & $\mathbf{2 0}(100 \%)$ & \\
\hline
\end{tabular}

$85 \%$ of the patients in group A and $75 \%$ of the patients in group B were males and $15 \%$ of the patients in group A and $25 \%$ in group B were females. By using chi-square test statistically no significant difference was found in the gender of the patients of two groups $(\chi 2$-value $=0.62, p=0.42)$.

Table 3: Distribution of patients in two groups according to their diagnosis

\begin{tabular}{cccc}
\hline Diagnosis & Group A & Group B & $\chi 2$-value \\
\hline Ca Gingiva & $0(0 \%)$ & $1(5 \%)$ & \\
Ca Alveolus & $1(5 \%)$ & $4(20 \%)$ & \\
CaBuccal Mucosa & $13(65 \%)$ & $9(45 \%)$ & \\
Ca Maxilla & $1(5 \%)$ & $0(0 \%)$ & 6.63 \\
Ca Tongue & $5(25 \%)$ & $4(20 \%)$ & $\mathrm{p}=0.35, \mathrm{NS}$ \\
Ca Hard Palate & $0(0 \%)$ & $1(5 \%)$ & \\
Ca Mandible & $0(0 \%)$ & $1(5 \%)$ & \\
\cline { 1 - 2 } Total & $\mathbf{2 0 ( 1 0 0 \% )}$ & $\mathbf{2 0}(100 \%)$ & \\
\cline { 1 - 2 } & & &
\end{tabular}


$5 \%$ of the patients in group B had Ca Gingiva, 5\% of the patients in group A and 20\% in group B had Ca Alveolus, $65 \%$ of the patients in group A and $45 \%$ in group B had CaBuccal Mucosa, 5\% of the patients in group A had Ca Maxilla, 25\% of the patients in group A and 20\% in group B had Ca. Tongue and each 5\% of the patients in group B had Ca Hard Palate and $\mathrm{Ca}$ Mandible. By using chi-square test statistically no significant difference was found in diagnosis of the patients of two $\operatorname{groups}(\chi 2$-value $=6.63, \mathrm{p}=0.35)$.

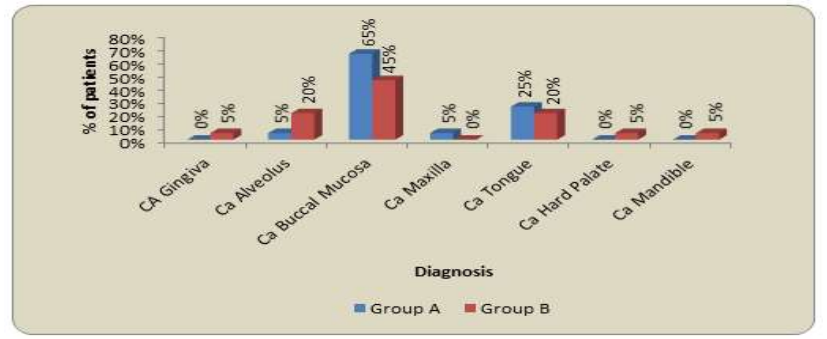

Graph 1: Distribution of patients in two groups according to their diagnosis

Table 4: Comparison of mouth opening with baseline in group A Student's Paired t test

\begin{tabular}{|c|c|c|c|c|c|c|c|}
\hline & Mean & $\mathbf{N}$ & Std. Deviation & SEM & Mean Difference & t-value & $p$-value \\
\hline Pre Op & 3.60 & 20 & 1.81 & 0.40 & - & - & - \\
\hline Immediate Post Op & 16.92 & 20 & 1.73 & 0.38 & $13.32 \pm 2.05$ & 29.01 & $0.0001, \mathrm{~S}$ \\
\hline After $1 \mathrm{mth}$ & 16.90 & 20 & 1.61 & 0.36 & $13.30 \pm 2.02$ & 29.31 & $0.0001, \mathrm{~S}$ \\
\hline After $2 \mathrm{mth}$ & 17.00 & 20 & 2.52 & 0.56 & $13.40 \pm 3.02$ & 19.78 & $0.0001, S$ \\
\hline After $3 \mathrm{mth}$ & 17.07 & 20 & 2.55 & 0.57 & $13.47 \pm 3.00$ & 20.04 & $0.0001, \mathrm{~S}$ \\
\hline
\end{tabular}

Mean pre operative mouth opening in group A was 3.60土1.81, immediate post operative mouth opening was $16.92 \pm 1.73$, mouth opening after 1 month was $16.90 \pm 1.61$, post operative mouth opening after 2 months was $17 \pm 2.52$ and postoperative mouth opening after 3 months was $17.07 \pm 2.55$. By using Student's paired $t$ test statistically significant difference was found in mean mouth opening at immediate post operative $(\mathrm{t}=29.01, \mathrm{p}=0.0001)$, post operative after 1 month $(\mathrm{t}=29.31, \mathrm{p}=0.0001)$, postoperative 2 months $(\mathrm{t}=19.78, \mathrm{p}=0.0001)$ and postoperative 3 months $(\mathrm{t}=20.04, \mathrm{p}=0.0001)$.

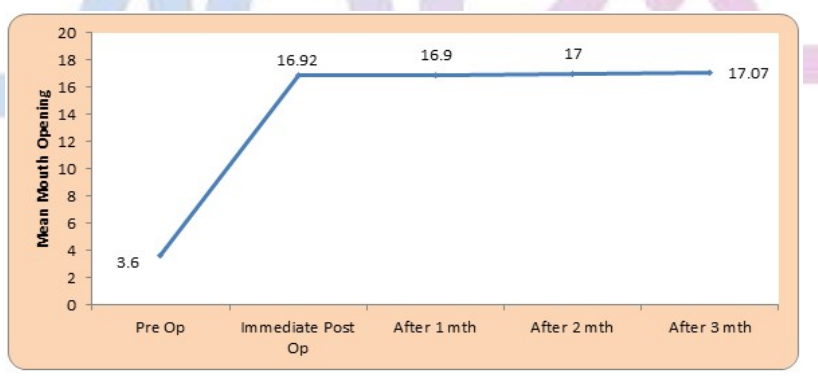

Graph 2: Comparison of mouth opening with baseline in group

\begin{tabular}{cccccccc}
\multicolumn{6}{c}{ Table 5: Comparison of mouth opening with baseline in group B Student's Paired t test } \\
\hline & Mean & $\mathbf{N}$ & $\begin{array}{c}\text { Std. } \\
\text { Deviation }\end{array}$ & $\begin{array}{c}\text { Std. Error } \\
\text { Mean }\end{array}$ & $\begin{array}{c}\text { Mean } \\
\text { Difference }\end{array}$ & t-value & p-value \\
\hline $\begin{array}{c}\text { Pre Op } \\
\text { Immediate Post Op }\end{array}$ & 3.45 & 20 & 1.39 & 0.31 & - & - & - \\
After 1 month & 13.25 & 20 & 1.11 & 0.25 & $9.80 \pm 1.23$ & 35.35 & $0.0001, \mathrm{~S}$ \\
After 2 month & 12.90 & 20 & 1.27 & 0.28 & $10.05 \pm 1.35$ & 33.13 & $0.0001, \mathrm{~S}$ \\
After 3 month & 12.90 & 20 & 2.24 & 0.50 & $9.45 \pm 2.23$ & 18.60 & $0.0001, \mathrm{~S}$ \\
\end{tabular}

Mean pre operative mouth opening in group A was $3.45 \pm 1.39$, immediate post operative mouth opening was $13.25 \pm 1.11$, mouth opening after 1 month was $13.50 \pm 1.27$, post operative mouth opening after 2 months was $12.90 \pm 2.24$ and postoperative mouth opening after 3 months was $12.90 \pm 2.19$. By using Student's paired t test statistically significant difference was found in mean mouth opening at immediate post operative $(\mathrm{t}=35.35, \mathrm{p}=0.0001)$, post operative after 1 month $(\mathrm{t}=33.13, \mathrm{p}=0.0001)$, postoperative 2 months $(\mathrm{t}=18.60, \mathrm{p}=0.0001)$ and postoperative 3 months $(\mathrm{t}=18.85, \mathrm{p}=0.0001)$. 


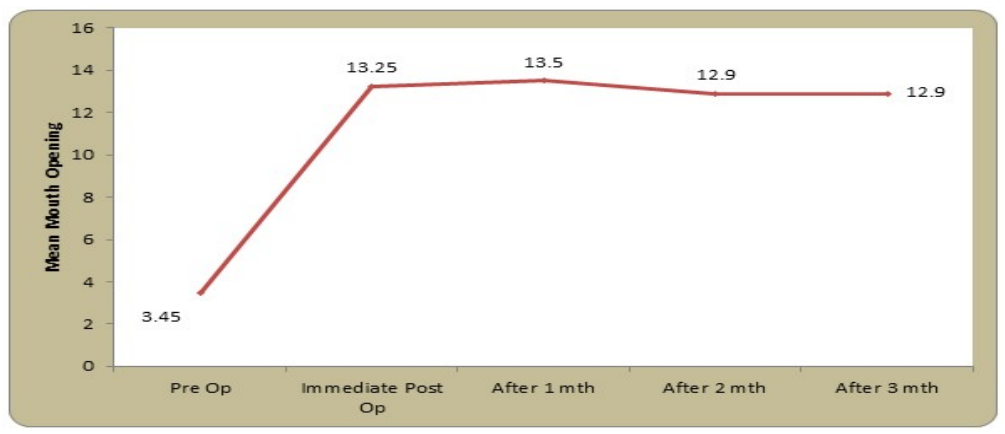

Graph 3: Comparison of mouth opening with baseline in group B

Table 6: Comparison of mouth opening in group A and group B Student's Unpaired t test

\begin{tabular}{|c|c|c|c|c|c|c|}
\hline & \multicolumn{2}{|c|}{ Group A } & \multicolumn{2}{|c|}{ Group B } & \multirow[t]{2}{*}{ t-value } & \multirow[t]{2}{*}{ p-value } \\
\hline & Mean & Std. Deviation & Mean & Std. Deviation & & \\
\hline Pre Op & 3.60 & 1.81 & 3.45 & 1.39 & 0.29 & $0.77, \mathrm{NS}$ \\
\hline Immediate Post Op & 16.92 & 1.73 & 13.25 & 1.11 & 7.96 & $0.0001, \mathrm{~S}$ \\
\hline After $1 \mathrm{mth}$ & 16.90 & 1.61 & 13.50 & 1.27 & 7.37 & $0.0001, \mathrm{~S}$ \\
\hline After 2 mth & 17.00 & 2.52 & 12.90 & 2.24 & 5.42 & $0.0001, S$ \\
\hline After $3 \mathrm{mth}$ & 17.07 & 2.55 & 12.90 & 2.19 & 5.54 & $0.0001, \mathrm{~S}$ \\
\hline
\end{tabular}

Mean pre operative mouth opening in group A was 3.60 \pm 1.81 and in group B it was $3.45 \pm 1.39$, immediate post operative mouth opening in group A was 16.92 \pm 1.73 , and in group B it was $13.25 \pm 1.11$, mouth opening after 1 month in group A was $16.90 \pm 1.61$ and in group B it was $13.50 \pm 1.27$, post operative mouth opening after 2 months in group A was $17 \pm 2.52$ and in group B it was was12.90 \pm 2.24 and postoperative mouth opening after 3 months in group A was $17.07 \pm 2.55$ and in group B it was $12.90 \pm 2.19$. By using Student's unpaired t test statistically significant difference was found in mean mouth opening at immediate post operative $(\mathrm{t}=7.96, \mathrm{p}=0.0001)$, post operative after $1 \operatorname{month}(\mathrm{t}=7.37, \mathrm{p}=0.0001)$, postoperative 2 months $(\mathrm{t}=5.42, \mathrm{p}=0.0001)$ and postoperative 3 months $(\mathrm{t}=5.54, \mathrm{p}=0.0001)$. No significant difference was found in mean mouth opening at baseline $(\mathrm{t}=0.29, \mathrm{p}=0.77)$.

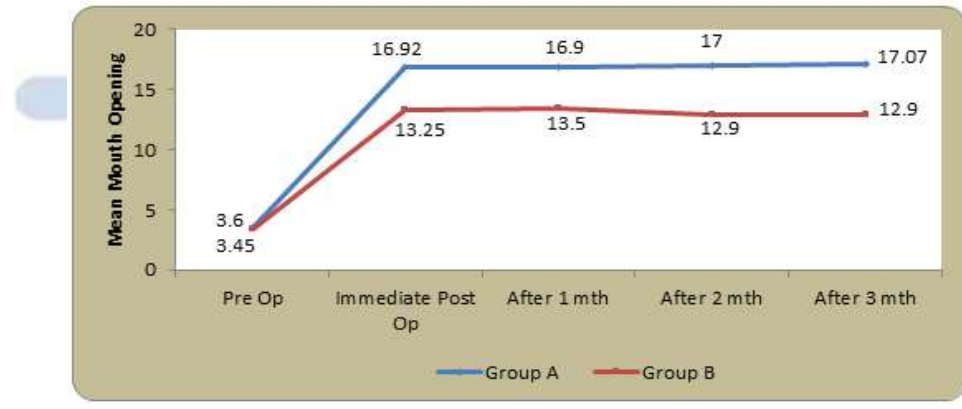

Graph 4: Comparison of mouth opening in group $A$ and group $B$

\section{DISCUSSION}

Radiotherapy and concomitant chemo radiotherapy are widely accepted curative approaches for organ preservation. Radiation induced fibrosis in surrounding tissue is common complication of the treatmentRadiation fibrosis further intensifies. Radiation injury results from two basic mechanism that is by direct DNA damage and generation of reactive oxygen species(ROS ).ionizing radiation interact with water molecule to form free radicals including superoxide, hydrogen peroxide, hydroxyl radical. These free radical damage cell component. These injured cells release chemo-attractant molecule that trigger nonspecific inflammation. As neutrophils are first cells to reach at the site of inflammation. when it interact with disrupted endothelial surface leads to extra-vastation of neutrophils. when they come in contact with collagen fragments and fibronectin they release TNF@,IL1,IL6.Next cells ate Monocytes and lymphocytes which interact with each other and transdifferentiate into macrophages. platelet derived growth factor secreted by macrophages promotes neoangiogenesis and stimulates migration of fibroblasts. They also secrete TGF beta which converts fibroblasts into myofibroblasts which secrets excess collagen and responsible for stiffness and thickness of the tissue.(Jeffery M.straub 2016) The limitations related to mouth opening, thus making mouth opening more difficult. The conventional exercise therapy as using tongue depressors, 
fingers and rubbers plugs has some effects for mean increase in mouth opening. (Dijkstra P U et al. 2007). Jaw stretching devices demonstrated efficacy in improving trismus in head and neck cancer patients. (Stubblefield M D et al. 2010, Buchbinder D et al. 1993, Cohen E G et al. 2005, Shulman D H et al. 2008) and Baranano C F et al. 2011). Exercise Dynasplint trismus system increased mouth opening satisfactorily. Exercises with TheraBite i.e. Jaw Motion Rehabilitation system increased mouth opening by many folds. TheraBite is a plastic device that is placed in the mouth and actuated with normal force applied in a leveraged fashion via plastic handles. Here Force is proportional to how hard the device handles are squeezed. Force is usually delivered near maximal patient tolerance for 7 seconds repeated for 7 times per day for 7 days. This device uses a high torque, short duration passive stretch which may result in painful rebound spasm of muscles of mastication. ( Buchbbinder D et al. 1993, Cohen E G et al. 2005 and Brown K E et al. 1968). Along with Therabite exercise we gave tab pentoxifylline and tab Tocopherol in one group as pentoxifylline is a methylxanthine derivative with hemorrheologic and immuno-modulating properties. Pentoxifylline inhibits phosphodiesterase, resulting in increased levels of cyclic adenosine monophosphate (cAMP) in erythrocytes, endothelium, and the surrounding tissues. This leads to vasodilatation, improves erythrocyte flexibility, and enhances blood flow In the present study of 20 patients, we have tried TheraBite application along with tab pentoxifylline and tab Tocopherol inradiation induced fibrosis treated with laser fibrotomy. In second group we gave Therabite exercise alone after doing laser fibrotomy The mouth opening was significantly increased after TheraBite application And using tab pentoxifylline and tab Tocopherol immediate postoperatively and increased mouth opening was sustained even up to 1 month, 2 months and 3 months Compared to Therabite application alone.

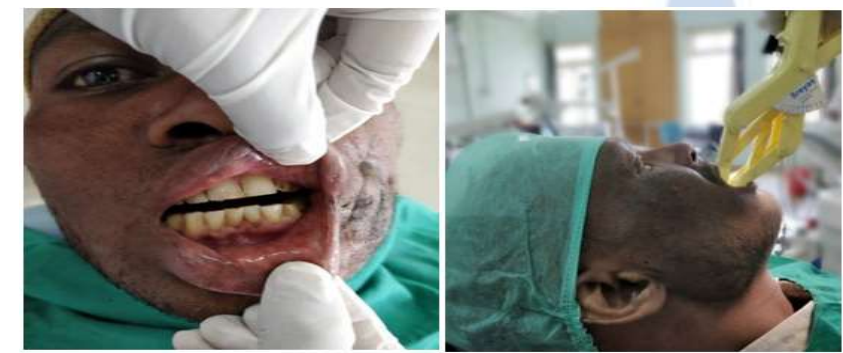

Figure 1

Pre operative mouth opening-3mm immediately after fibrotomy-8mm

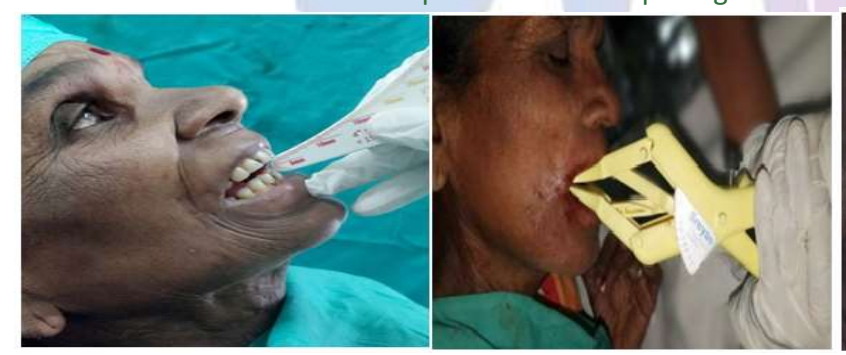

Figure 3

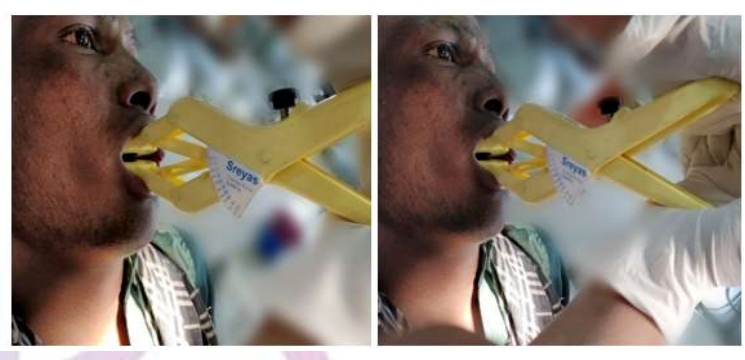

Figure 2

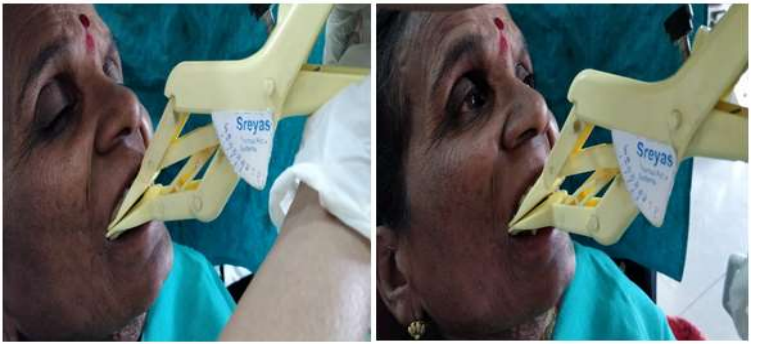

Figure 4

Figure 1: Pre operative mouth opening-3mmMouth opening immediately afterfibrotomy 10mm GROUP A GROUP A; Figure 2: Mouth opening after I month of fibrotomy-15mm mouth opening $17 \mathrm{~mm}$ after $2^{\text {nd }}$ and $3^{\text {rd }}$ month (GROUP A ) (GROUP A); Figure 3: (Group B ) pre op mouth opening-3mm (Group B)immediately after fibrotomy-8mm; Figure 4: (GROUP B) 1 month after fibrotomy-10mm (GROUP B)-2 ${ }^{\text {nd }}$ and $3^{\text {rd }}$ month after fibrotomy-13mm

\section{CONCLUSION}

From the present study it can be concluded that, jaw stretcher TheraBite application along with $\mathrm{Tab}$ pentoxifylline 400mg TDSfor two months and Tab Tocopherol 1000 iuOD for two months, is effective in increasing the mouth opening in patients with RIF secondary to radiotherapy in oraland head and neck cancer It effectively increases the mouth opening as compared to preoperative readings and sustains it for a period up to $2-$
3 monthsand above without any untoward effects. With this it improves the quality of health, speech, chewing, swallowing and pain relief in these patients. Thus a simple instrument like TheraBite can be more useful in patients with Radiation induced fibrosis having difficulty in mouth opening. It is simple, light weight, easy to handle, cost effective, easy to use can be asked to use at home without hospitalization. In all aspects it is efficient and beneficial for all these needy patients. 


\section{REFERENCES}

1. Jolanda I Kamstra, Jan L N Roodenburg, Carien H G Beurskens-Harry Reintsems, Peter U Dijkstra (2013) : TheraBIteexcercises to treat trismus secondary to head and neck cancer - Support care Cancer (2013) 21 : 951-957

2. Buchbinder D, Currivan R B, Kaplan A J ,Urken M L (1993) : Mobilization regimens for the prevention of jaw hypomobility in radiated patient : a comparison of three techniques. J Oral MaxillofacSurg 51, 863-867

3. Cohen E G, Deschler D G, Walsh K, Hayden R E (2005) : Early use of a mechanical stretching device to improve Mandibular mobility after composite resection. A pilot study. Arch Phys Med Rehabili86 : 1416-1419.

4. Brown K E (1968) : Dynamic opening device for Mandibular trismus : J Prosthet Dent 20, 489-42.

5. Stubblefield M D, Manfield L, Riedel E R (2010) : A preliminary report on the efficacy of dynamic jaw opening device (dynasplint trismus system) a part of the multimodel treatment of trismus in patients with head and neck cancer. Arch Phys Med rehabilt 91, 1278-1282.

6. Shulman D H, Shiprman B, Willis F B (2008) : Treating trismus with dynamic splinting, a cohort case series AdvTher 25, 9-16.
7. L JU Melchers, E Van Weert, C H G Beurskens, H reintsema, A P Slagter, J L n Roodenburg and P U Dijkstra (2009) Exercise adherence in patients with trismus due to head and neck oncology : a qualitative study into the use of TheraBite IntJr Oral MaxillofacSurg 38 : 947-954.

8. Michel D Stubblfield, M D Laura Manfield, M D Elyn R Riedel M A : A preliminary report on the Efficacy of a Dynamic Jaw Opening Device ( Dynasplint Trismus System) as part of the multimodel treatment of trismus in patients with head and neck cancer : Arch Phys Med RehabiltVol 91, 1278-1282.

9. Yu Hsuan, Wei Chin Chang, Tien En Chiang, ChiunShu Lin, Yaun Wu Chen (2018), Mouth opening device as a treatment modality in trismus patients with head and neck cancer and oral submucus fibrosis : a prospective study , published online https:/doi.org/10.1007/s00784-0182456-

10. Okunieff P, Augustine E, et al. Pentoxifylline in the treatment of radiation-induced fibrosis. Journal of clinical oncology. 2004 Apr;22(11):2207-13.

11. Chua DT, Lo C, Yuen J, Foo YC. A pilot study of pentoxifylline in the treatment of radiation-induced trismus. American journal of clinical oncology. 2001 Aug 1;24(4):366-9.

\section{Source of Support: None Declared Conflict of Interest: None Declared}

Policy for Articles with Open Access:

Authors who publish with MedPulse International Journal of Dentistry (Print ISSN:2579-1125) (Online ISSN: 2636-4603) agree to the following terms: Authors retain copyright and grant the journal right of first publication with the work simultaneously licensed under a Creative Commons Attribution License that allows others to share the work with an acknowledgement of the work's authorship and initial publication in this journal.

Authors are permitted and encouraged to post links to their work online (e.g., in institutional repositories or on their website) prior to and during the submission process, as it can lead to productive exchanges, as well as earlier and greater citation of published work. 